\title{
Impact of Abiotic Stress on Quality Traits of Maize Forage at Two Growth Stages
}

\author{
S. H. Mohammed ${ }^{1, a}$ and M. I. Mohammed ${ }^{2, b^{*}}$ \\ ${ }^{1}$ Forage \& Range Research Program, Soba Research Station, Khartoum, Sudan. \\ ${ }^{2}$ Forage Improvement Program, Agricultural Research Corporation (ARC), Khartoum North, Sudan \\ a sawsanhassbo@gmail.com, b maaroufibrahim@gmail.com
}

Keywords: NDF, ADF, CP, dough stage, silk initiation.

\begin{abstract}
Maize (Zea mays L.) forage quality traits are reported to show varying responses to abiotic stress. Four trials were conducted in Sudan (Africa) during the summer and winter seasons (2013 2014) at two locations: Shambat (normal soils) and Soba (salt affected soils) to investigate the effects of heat, water, and salt stresses on the nutritive value of maize forage. In each trial nine maize genotypes were studied under two watering regimes arranged in split plot experiment in randomized complete block design. The compound effect of salt, water and heat stresses created by the combination of locations, seasons and watering regimes were used to investigate the effect of abiotic stress on forage quality at silk initiation and dough growth stages. Character associations under stressed and none stressed conditions were studied. NDF, ADF, CP, forage yield and related traits were measured. Abiotic stress significantly lowered the nutritive value in terms of crude protein, digestibility and intake potential. Digestibility under stressed condition was slightly improved as growth stage advanced from silk initiation to dough stage. Correlations under non stress conditions between forage yield and quality traits were either favorable with NDF and weak or insignificant with $\mathrm{ADF}$ and $\mathrm{CP}$. Under stress conditions, similar trend generally exists apart from the unfavorable correlation of $\mathrm{CP}$ with each of yield and ADF, in addition to earliness with NDF. The compound effect of salt, water and heat stresses have adverse impact on the nutritive value of maize forage. Varieties combining high performance in quality and forage yield could be developed under nonstressed or stressed conditions.
\end{abstract}

\section{Introduction}

Maize (Zea mays L.) is the World's primary source for animal feed [1]. It is the only crop amongst non-leguminous combining high quantity of biomass along with better nutritional quality. Forage maize has become a major constituent of ruminant rations in recent years, where its inclusion in dairy cow diets improves forage intake and animal performance $[2,3]$

Although the crop has wide adaptability [4] it is the least tolerant to abiotic stresses among cereals. Moisture, salinity and elevated temperatures are among the major abiotic stresses that negatively impact maize performance worldwide [5-8]. Salinity effected soils occur in all continents specially in the arid and semi-arid regions compared to humid regions [9]. The total salt-affected soils in Sudan amounts to 4.8 million hectares [10]. Currently, 50\% of all irrigation schemes are affected by salinity. The influence of abiotic stress on the quality of forage crops has been reported by many workers [11-13]. Crop growing season and plant developmental stages are other important factors that influence the forage quality [14]. Incidence of stress at any stage may influence the feed and forage digestibility and reduced nutrient intake [15]. However, varying results on how stress affects the feed quality have been reported. While all ozone studies reported reduced digestibility of plant materials grown under stress, most studies dealing with drought reported an enhanced feed value, while mixed or no effects were seen under salinity, and heat stress [16]. Another factor determining forage quality is the growth stage. Intake potential decreases and NDF concentration increases with advancing maturity. Also, the rate at which fiber is digested slows as plants mature [17]. Associations among characters are of interest to the breeder to point out the possibilities and limitations of simultaneous improvement of desirable characters [18] especially those dealing with agronomic and 
quality traits. However, such studies were mostly carried under normal conditions with very few ones considering the nature of associations under stress conditions. The objectives of this study were to investigate the effects of abiotic stress on forage quality and character associations in maize grown under stressed and normal conditions.

\section{Materials and Methods}

The study was conducted in Sudan (Khartoum State) during 2013-2014 at two different locations: Shambat (Lat. $15^{\circ} 39^{\prime} \mathrm{N}$; Long. $32^{\circ} 31^{\prime} \mathrm{E}$; Alt 380 masl) and Soba (Lat. $15^{\circ} 24^{\prime} \mathrm{N}$; Long. $32^{\circ}$ $32^{\prime} \mathrm{E}$; Alt 380 masl). Soba is located about $25 \mathrm{~km}$ south of Shambat. In each location the trial was carried out in the Experimental Farm of the Agricultural Research Corporation (ARC).

\section{The plant material}

Nine maize genotypes comprising 8 hybrids +1 open pollinated cultivar were studied (Table 1).

Table 1. Plant material used in the study

\begin{tabular}{llll}
\hline S.N. & Genotype & Type/Color & Source \\
\hline 1 & PAN-6966 & Yellow maize hybrid & South Africa \\
2 & PAN-12 & Yellow maize hybrid & South Africa \\
3 & PAN-14 & Yellow maize hybrid & South Africa \\
4 & PAN-6P110 & Yellow maize hybrid & South Africa \\
5 & Hytech1100 & White maize Hybrid & Egypt \\
6 & Hytech2066 & Yellow maize hybrid & Egypt \\
7 & Hytech2031 & White maize hybrid & Egypt \\
8 & Hytech2055 & Yellow maize hybrid & Egypt \\
9 & Hudieba2 & Yellow maize (open pollinated ) & Sudan \\
\hline
\end{tabular}

\section{Test-environments}

The above maize genotypes were subjected to normal vs stressed environments representing water, heat and salt stresses and their combinations as follows:

1. Normal vs water stress was brought about by adopting watering regimes of one and two week intervals, respectively.

2. Normal temperature vs heat stress was brought about by sowing in winter and summer seasons, respectively.

3. Normal soil vs salt stress was brought about by planting in Shambat and Soba locations, respectively.

The soils at Shambat are well drained loamy clay, non-saline and non-sodic with $\mathrm{pH}$ ranging 7.7 - 7.9). The soil at Soba is hazarded by salinity $(\mathrm{ECe}=12-14 \mathrm{dS} / \mathrm{m})$ and sodicity $(\mathrm{ESP}=24-27)$, $(\mathrm{SAR}=16-23)$, with high clay content, low infiltration and permeability, low organic matter and nitrogen and high $\mathrm{pH}$ ).

The average min-max temperature during the winter season (Nov. - Feb.) ranged $15-20^{\circ} \mathrm{C}$ and $32-38^{\circ} \mathrm{C}$ whereas that at summer (April-July) ranged $25.0-28.4^{\circ} \mathrm{C}$ and $36.9-42.0^{\circ} \mathrm{C}$. The weather is dry in both growing seasons specially during Winter.

\section{The experimental design and cultural practices}

To achieve the above treatment combinations 4 trials were conducted 2 at each location (Shambat and Soba) in each season (winter and summer). Each trial was split plot experiment with watering regimes assigned to the main plots and the genotypes to the sub plots in a randomized 
complete block design (RCBD) with three replications. The combination of location, season and watering regime $(2 \times 2 \times 2)$ provided 8 stress levels (Table 2$)$ used to test the genotypes at silk initiation and milk stages. Quality traits were studied using material subjected to stress levels No 1 (No stress) and No 8 (Full stress) (Table 2)

Table 2. Abiotic stress levels generated from different combinations of environmental conditions

\begin{tabular}{lllll}
\hline S.No. & Stress level & location & Season & Water \\
\hline 1 & No stress & Shambat & Winter & Normal \\
2 & Water stress & Shambat & Winter & Stressed \\
3 & Heat stress & Shambat & Summer & Normal \\
4 & Water + heat stress & Shambat & Summer & Stressed \\
5 & Salt stress & Soba & Winter & Normal \\
6 & Water + salt stress & Soba & Winter & Stressed \\
7 & Salt + heat stress & Soba & Summer & Normal \\
8 & Full stress & Soba & Summer & Stressed \\
\hline
\end{tabular}

Unless otherwise indicated, the cultural practices followed were the same in all trials. The land was disc ploughed, disc harrowed and levelled by scraper to obtain fine seed bed. Ridging was done at $0.75 \mathrm{~m}$ spacing. The plot consisted of four ridges $4 \mathrm{~m}$ long. Two seeds were placed in holes spaced at $15 \mathrm{~cm}$ on one side of the ridge. The winter sowings were done on the $8^{\text {th }}$ and $12^{\text {th }}$ of Dec. 2013 in Soba and Shambat, respectively. Summer sowings were done on the $13^{\text {th }}$ and $19^{\text {th }}$ of May 2014 in Soba and Shambat, respectively. Nitrogen fertilizer $(55 \mathrm{kgN} / \mathrm{ha})$ was applied in a form of urea at the second watering. Weed population was kept to minimum by hand weeding.

\section{Data collection}

Proximate analysis for the following quality traits were studied on dry matter basis at silk initiation and dough stages using material from fully normal and fully stressed treatments:

1. Neutral detergent fiber (NDF)

2. Acid detergent fiber (ADF)

3. Crude protein $(\mathrm{CP})$

The chemical analysis was done following the standard procedure of the AOAC [19]. Crude protein was analyzed using micro-kjeldhal method. The $\mathrm{CP}$ in each sample was estimated from total nitrogen using the numerical conversion factor $=6.25$. The chemical analysis was carried out in the Laboratory of Animal Production - Shambat - University of Khartoum.

Agronomic traits recorded included: dry matter yield (DMY), days to 50\% tasselling, plant height and stem diameter.

\section{Statistical analysis}

The data collected were subjected to the standard procedure of analyzing split plot in RCB design [20]. The combined analysis of variance of the genotypes across the stress levels was performed using the statistical package GenStat [21]. Pearson's correlation coefficients between quality and agronomic traits at dough stage were calculated.

\section{Results}

\section{Effects of abiotic stress}

Table 3 shows mean squares of genotypes, environments, growth stage and their interactions for neutral detergent fiber (NDF), acid detergent fiber (ADF) and crude protein (CP). The analysis of variance revealed highly significant differences among genotypes, environments and growth stage for the three studied traits. The first and second order interactions of the main effects were also highly significant for the three studied traits. 
Table 3. Mean squares of the main and interaction effects for some quality traits of maize forage (2013-2014)

\begin{tabular}{lllll}
\hline \multicolumn{1}{c}{ Source of variation } & DF & \multicolumn{1}{c}{ NDF $\dagger$} & \multicolumn{1}{c}{ ADF $\dagger$} & \multicolumn{1}{c}{ CP $\dagger$} \\
\hline Block & 2 & 0.3220 & 0.03028 & 0.21714 \\
Environments (E) & 1 & $1378.8064^{* *}$ & $1284.15933^{* *}$ & $64.82256^{* *}$ \\
Growth stages (H) & 1 & $5.7362^{* *}$ & $29.77800^{* *}$ & $24.64282^{* *}$ \\
Genotypes (G) & 8 & $37.9792^{* *}$ & $163.50119^{* *}$ & $10.66437^{* *}$ \\
$\mathrm{E} \times \mathrm{H}$ & 1 & $8.9039^{* *}$ & $155.06433^{* *}$ & $0.94285^{* *}$ \\
$\mathrm{E} \times \mathrm{G}$ & 8 & $16.3440^{* *}$ & $81.92183^{* *}$ & $11.89984^{* *}$ \\
$\mathrm{G} \times \mathrm{H}$ & 8 & $21.3543^{* *}$ & $43.02976^{* *}$ & $1.68034^{* *}$ \\
$\mathrm{G} \times \mathrm{W} \times \mathrm{E}$ & 8 & $24.6541^{* *}$ & $116.40048^{* *}$ & $2.10763^{* *}$ \\
Residual & 70 & 0.2524 & 0.01504 & $0.04994^{* *}$ \\
\hline$:$ Neutral detergent fiber (NDF) & & & \\
$:$ Acid detergent fiber (ADF) & & & &
\end{tabular}

\section{Genotypic effects}

Table 4 shows the performance of genotypes for the three quality traits. The hybrid PAN12 scored the lowest NDF value (65.8\%) followed by Hytech2031 (66.6\%). PAN6P-110 and PAN6966 scored the highest NDF value (above 70\%). The hybrid Hytech2066 exhibited the lowest ADF value (38.4\%), followed by PAN12 (38.5\%). PAN6966 scored the highest ADF value (46.3\%). The highest CP values were scored by PAN12 (12.6\%), Hytech2066 and PAN6966 (11.1\%) whereas the lowest value was shown by Hytech2055 (9.59\%).

Table 4. Neutral detergent fiber (NDF), acid detergent fiber (ADF) and crude protein (CP) of maize forage (2013-2014)

\begin{tabular}{llll}
\hline Genotypes & NDF ( percentage) & ADF ( percentage) & CP ( percentage) \\
\hline PAN6966 & 71.0 & 46.3 & 11.1 \\
PAN12 & 65.8 & 38.5 & 12.6 \\
PAN14 & 68.6 & 45.7 & 10.3 \\
PAN6P-110 & 71.2 & 48.4 & 9.66 \\
Hytech1100 & 68.3 & 41.3 & 10.3 \\
Hytech2066 & 68.2 & 38.4 & 11.1 \\
Hytech2031 & 66.6 & 38.8 & 9.95 \\
Hytech2055 & 69.1 & 41.3 & 9.59 \\
Hudeiba2 & 68.1 & 41.5 & 10.4 \\
\hline Mean & 68.5 & 42.3 & 10.6 \\
SE \pm & 0.1450 & 0.0354 & 0.0645 \\
LSD (5\%) & 0.4091 & 0.0999 & 0.2573 \\
CV (\%) & 0.7 & 0.3 & 2.1 \\
\hline
\end{tabular}

\section{Effect of stress levels and growth stage}

Tables 5 and 6 show the effect of abiotic stress and growth stage on forage quality traits, respectively. Stressed condition increased NDF (72.1\%), ADF (45.7\%) and decreased CP (9.79\%) as compared to normal condition. The respective values for non-stress condition were $65.0 \%, 38.8 \%$ and $11.3 \%$. Table 6 shows that harvesting at dough stage significantly reduced CP $(10.1 \%)$ as compared to silk initiation stage (11.0\%). The NDF values at silk initiation and dough stage were $68.3 \%$ and $68.7 \%$, respectively. The ADF at dough stage was lower $(41.7 \%)$ than that of silk initiations (42.8\%). 
Table 5. Effect of stress level on some quality traits of maize forage (2013-2014)

\begin{tabular}{llll}
\hline Environments & $\mathrm{NDF} \dagger$ & $\mathrm{ADF} \dagger \dagger$ & $\mathrm{CP} \dagger$ \\
\hline Non-stress condition & 65.0 & 38.8 & 11.3 \\
Stress condition & 72.1 & 45.7 & 9.79 \\
\hline Mean & 68.5 & 42.3 & 10.6 \\
$\mathrm{SE} \pm$ & 0.0684 & 0.0167 & 0.0304 \\
$\mathrm{CV}(\%)$ & 0.7 & 0.3 & 2.1 \\
\hline
\end{tabular}

$\dagger:$ Neutral detergent fiber (NDF)

$\dagger$ : Acid detergent fiber (ADF)

\$: Crude protein $(\mathrm{CP}$

Table 6. Effect of growth stage on some quality traits of maize forage (2013-2014)

\begin{tabular}{llll}
\hline Growth stage & NDF $\dagger$ & ADF $\dagger \dagger$ & CP $\dagger$ \\
\hline Silk initiation stage & 68.3 & 42.8 & 11.0 \\
Dough stage & 68.8 & 41.7 & 10.1 \\
\hline Mean & 68.5 & 42.3 & 10.6 \\
$\mathrm{SE} \pm$ & 0.0684 & 0.017 & 0.0304 \\
$\mathrm{CV}(\%)$ & 0.7 & 0.3 & 2.1 \\
\hline
\end{tabular}

$\dagger$ : Neutral detergent fiber (NDF)

$\dagger \dagger$ : Acid detergent fiber (ADF)

$\$$ : Crude protein $(\mathrm{CP})$

\section{Interaction effect}

Table 7 shows the interaction effect of stress level with growth stage on quality traits. Harvesting at dough stage under normal condition didn't significantly altered NDF value compared to harvesting at silk initiation stage. However, under stressed condition harvesting at dough stage significantly increased NDF (72.7\%) compared to harvesting at silk initiation stage (71.6\%). Harvesting at dough stage under stressed condition significantly decreased ADF value (44.0\%) compared to harvesting at silk initiation stage (47.4\%). Harvesting at dough stage significantly decreased CP percentage under normal $(11.0 \%)$ and stressed conditions as well $(9.22 \%)$. The respective values for $\mathrm{CP}$ obtained by harvesting at silk initiation were $11.7 \%$ and $10.4 \%$.

Table 7. Interaction effect of stress level with growth stage on percentage neutral detergent fiber (NDF), acid detergent fiber (ADF) and crude protein (CP) in maize forage (2013-2014)

\begin{tabular}{|c|c|c|c|c|c|c|}
\hline \multirow[b]{2}{*}{ Growth stage } & \multicolumn{2}{|l|}{ NDF } & \multicolumn{2}{|l|}{ ADF } & \multicolumn{2}{|l|}{$\mathrm{CP}$} \\
\hline & Silk initiation & Dough & Silk initiation & Dough & Silk initiation & Dough \\
\hline Normal condition & 65.0 & 64.9 & 38.1 & 39.5 & 11.7 & 11.0 \\
\hline Stress condition & 71.6 & 72.6 & 47.4 & 44.0 & 10.4 & 9.22 \\
\hline Mean & \multicolumn{2}{|c|}{68.5} & \multicolumn{2}{|c|}{42.3} & \multicolumn{2}{|l|}{10.6} \\
\hline $\mathrm{SE} \pm$ & \multicolumn{2}{|c|}{0.0967} & \multicolumn{2}{|c|}{0.0236} & \multicolumn{2}{|c|}{0.0430} \\
\hline $\operatorname{LSD}(5 \%)$ & \multicolumn{2}{|c|}{0.2727} & \multicolumn{2}{|c|}{0.0666} & \multicolumn{2}{|c|}{0.1213} \\
\hline CV $(\%)$ & \multicolumn{2}{|c|}{0.7} & \multicolumn{2}{|c|}{0.3} & \multicolumn{2}{|c|}{2.1} \\
\hline
\end{tabular}

\section{Associations under non-stress and stress conditions}

Table 8 shows correlation among quality and agronomic traits under non-stress conditions. DMY had negative highly significant correlations with ADF $(r=-0.4975)$. Correlations were weak and insignificant between DMY with NDF and CP. Plant height had negative significant correlation with ADF ( $\mathrm{r}=-0.4537)$ and insignificant correlation with NDF and CP. Days to tasselling had positive significant correlation with NDF $(r=0.3579)$ and ADF $(r=0.3592)$ but had negative and highly significant correlations with $\mathrm{CP}(\mathrm{r}=-0.6302)$. Correlation between stem diameter and $\mathrm{CP}$ was significantly negative $(\mathrm{r}=-0.3602)$ whereas it was insignificant with NDF and ADF. CP had negative 
highly significant correlations with ADF $(\mathrm{r}=-0.5336)$ but had weak insignificant correlation with NDF. A positive significant correlation was observed between NDF and ADF $(r=0.4121)$.

Table 9 shows the correlation among different maize attributes under stressed conditions. DMY had negative highly significant correlation with CP $(\mathrm{r}=-0.5288)$. Correlations were weak and insignificant between DMY and each of NDF and ADF. Plant height had negative significant correlation with CP $(\mathrm{r}=-0.4014)$. Correlations were weak and insignificant between plant height and each of NDF and ADF. Days to tasselling had negative significant correlation with NDF ( $\mathrm{r}=-0.3343)$. Correlations were weak and insignificant between days to tasselling and each of CP and ADF. Correlation between stem diameter and $\mathrm{CP}$ were positive and highly significant $(\mathrm{r}=0.7055)$. Correlations were weak and insignificant between stem diameter and each of NDF and ADF. Positive significant correlation was observed between $\mathrm{CP}$ and $\mathrm{ADF}(\mathrm{r}=0.3374)$. Correlations between $\mathrm{CP}$ and NDF and between NDF and ADF were weak and insignificant.

Table 8. Correlation among different forage maize attributes under non-stressed conditions

\begin{tabular}{llllllll}
\hline \multicolumn{1}{c}{ Character } & & 1 & 2 & 3 & 4 & 5 & 6 \\
\hline NDF & 1 & - & & & & & \\
Stem diameter & 2 & 0.1503 & - & & & & \\
Plant height & 3 & -0.2211 & $0.5160 * *$ & - & & & \\
Days to tassling & 4 & $0.3579 *$ & $0.7995^{* *}$ & $0.4556 *$ & - & & \\
ADF & 5 & $0.4121 *$ & 0.0693 & $-0.4537 *$ & $0.3592 *$ & - & \\
CP & 6 & -0.0238 & $-0.3602 *$ & -0.0708 & $-0.6302 * *$ & $-0.5336 * *$ & - \\
DMY & 7 & -0.1591 & $0.5728^{* *}$ & $0.9005^{* *}$ & $0.3938^{*}$ & $-0.4975^{* *}$ & 0.1371 \\
\hline \multirow{2}{*}{$* * *=$ significantly different from zero at 0.05 and 0.01 probability level, respectively. } &
\end{tabular}

Table 9. Correlation among different forage maize attributes under stressed condition

\begin{tabular}{llllllll}
\hline \multicolumn{1}{c}{ Character } & 1 & 2 & 3 & 4 & 5 & 6 \\
\hline NDF & 1 & - & & & & & \\
Stem diameter & 2 & -0.0318 & - & & & & \\
Plant height & 3 & -0.2034 & -0.3001 & - & & & \\
Days to tassling & 4 & $-0.3343^{*}$ & 0.0119 & $0.3703^{*}$ & - & & \\
ADF & 5 & -0.2853 & 0.0126 & 0.1774 & -0.2170 & - & \\
CP & 6 & -0.2840 & $0.7055^{* *}$ & $-0.4014^{*}$ & 0.1105 & $0.3374^{*}$ & - \\
DMY & 7 & -0.1539 & $-0.3715^{*}$ & $0.8131^{* *}$ & $0.4143^{*}$ & 0.0328 & $-0.5288^{* *}$ \\
\hline$* * *$
\end{tabular}

\section{Discussion}

\section{Forage quality}

The highly significant differences noted among genotypes for NDF, ADF, and crude protein (CP) indicated that a considerable portion of the variability observed for these traits was due to genetic factors irrespective of the effects of stressed conditions and growth stage. However, the interaction of genotypes with growth stages and stressed conditions was highly significant indicating that the genotypes performed inconsistently across these factors.

The performance of the maize genotypes for the cell wall fraction and crude protein shown by this study was within the range reported in the literature [22]. However, two hybrids, namely, PAN6966 and PAN6P-110 showed above range values for ADF ( $\geq 48 \%$ ). Such results should be cautiously considered as it might be due to sampling error.

The ADF predicts digestibility [14] while the NDF measures the intake potential [23]. Lower values are desirable for each measurement. In the present study stressed conditions (compound effect of heat, salt and water stresses) significantly lowered the nutritive value of forage maize in terms of 
crude protein content, digestibility and intake potential. Supporting results were reported by Montgomery [24]. Some disagreeing studies pointed that drought stress has no effect on percentage of crude protein of maize forage [24, 25] while others reported that drought has enhanced feed value, whereas salinity and heat stresses have mixed or no effects [16]. However, we think that drought stress joined with salt and heat stresses (as in this study) will have deleterious effects on the spectrum of nutritive elements since the compound effect of these factors will impede uptake of nutrients reported to play significant role on the content of crude protein [13].

In the present study crude protein percentage significantly decreased as growth stage advanced from silk initiation to the dough stage, however, the dough stage has lower ADF value than silk initiation. This could be explained by the diluting effect of the low ADF content reported for the developed ears and husks in the dough stage [26].

The quality of forage maize at dough stage was reported to be the ideal after which it starts to decline [1]. Also the forage yield and the energy value at dough stage are expected to be better than that at silk initiation due increased plant size and starch formation. At silk initiation, however, 'baby corn' or immature cobs represents additional source of income to the farmer in urban and semi-urban areas.

\section{Characters associations}

The correlations between quality traits and forage yield shown by this study pointed to the possibility of developing or identifying cultivars superior in both yield and digestibility, on the other hand the week and insignificant correlation between yield and each of NDF and protein content may allow for selecting high yielding genotypes with good potential intake and protein content. These results agree with those reported by Silva [27] who concluded that the variability and correlations of traits in forage maize permit selection for quality traits while maintaining yield or vise versa. Disagreeing results were reported in maize [28] and forage sorghum [29]. Correlation among quality traits shown in this study were favorable specially under non-stressed conditions showing the possibility of selecting forage maize genotypes having good levels of protein content, digestibility and potential intake. Similar results, but in forage sorghum were reported [29].

Under stress conditions, the correlation of forage yield with other traits showed no contrasting differences compared to those under non-stressed conditions. This may ease the role of the breeder working on parallel improvement of forage yield and quality traits under stressed conditions since he may make use of the elite materials developed under normal conditions. However, some correlations were quite the opposite to those under non-stress conditions where unfavorable correlation exists between crude protein with each of forage yield $(\mathrm{r}=-0.5288)$, digestibility $(\mathrm{r}=0.3374)$ and plant height $(\mathrm{r}=-0.4014)$. Similarly, days to tasselling (earliness) had unfavorable correlation with intake potential $(\mathrm{r}=-0.3343)$. This may partially be attributed to the effect of abiotic stresses reported to affect every aspect of plant growth, which includes anatomical and morphological growth, physiological and biochemical processes [30-32].

\section{Conclusions}

The compound effect of salt, water and heat stresses has the greatest adverse effect on the nutritive value of forage maize in terms of crude protein content, digestibility and intake potential. Maize varieties combining high performance in quality and forage yield under non-stressed conditions could be developed. Such materials could also work under stressed conditions

\section{Conflict of Interest}

The authors declare that there is no conflict of interest. 


\section{References}

[1] D.P. Chaudhary et al., Maize as fodder; an alternative approach, Directorate of Maize Research, Pusa Campus, New Delhi -110 012, Technical Bulletin. 2012/04 (2012) 32 p.

[2] L.J. Anil, R.H. Phipps, The potential of forage-maize intercrops in ruminant nutrition, Animal Feed Science and Technology. 85 (2000) 157-164.

[3] J.A. Cusicanqui, J.G. Lauer, Plant density and hybrid influence on corn forage yield and quality, Agro. J. 91 (1999) 911-915.

[4] M. Koutsika- Sotiriou, Hybrid seed production in maize, In: A.S. Basra (Ed.), Heterosis and hybrid seed production in agronomic crops, Food Products Press, NewYork. (1999) 25-64.

[5] M. Cooper et al., Breeding drought-tolerant maize hybrids for the US corn-belt: Discovery to product, J. Exp. Bot. (2014). doi: 10.1093/jxb/eru064.

[6] I. Ahuja, R.C. de Vos A.M. Bones, Plant molecular stress responses face climate change, Trends Plant Sci. 15 (2010) 664-674.

[7] R. Ngara, R. Ndimba J.B. Jensen, Identification and profiling of salinity stress-responsive proteins in Sorghum bicolor seedlings, J.Proteomics. 75 (2012) 4139-4150.

[8] W. Schlenker, M.J. Roberts, Nonlinear temperature effects indicate severe damages to U.S. crop yields under climate change, Proc. Nat. Acad. Sci. USA. 106 (2009) 15594-15598.

[9] J.D. Oster, R.C. Reeve M. Fireman, Salt problems in relation to irrigation, In: Irrigation of agricultural lands (ed. by R. M. Hagen). Agronomy J. 11 (1967) 988-1008.

[10] FAO, The use of saline waters for crop production - FAO irrigation and drainage paper 48, Available at: http://www.fao.org/docrep/t0667e/t0667e00.HTM. (2000).

[11] S. Mahmood et al., Heat stress effects on forage quality characteristics of maize (Zea mays L) cultivars, Int. J. Agric. Biol. 12 (2010) 701-706.

[12] D. Vincent et al., Water deficits affect caffeate o-methyltransferase, lignification, and related enzymes in maize leaves, A proteomic investigation. Plant Physiol. 137 (2005) 949-960.

[13] C.S. Dannhauser, The herbage yield and quality of three grass species on two marginal maize soils at Potchefstroom, J. of the Grass land Society of Southern Africa. 8 (1991) 120 -121.

[14] R. Mitchell et al., Predicting forage quality in switch grass and big bluestem, Agron. J. 93 (2001) 118-124.

[15] K.E. Turner et al., Mefluldlde treatment of tall fescue pastures: forage quality, J. Anim. Sci. 68 (1990) 3406-3411.

[16] M.S. Alien et al., Variation in fiber content and fiber digestibility of corn forages Minnesota Forage, Late Summer 1992, Mich. State Univ., East Lansing, MI. Vol. XV 11 No. 4 (1992).

[17] M.A. Bal et al., Corn silage hybrid effects on intake, digestion, and milk production by dairy cows, J. Dairy Sci. 83 (2000) 2849-2858.

[18] H.A. Abdalla, Evaluation of exotic and local parental lines of sorghum (Sorghum bicolor L. Moench) and their F1 hybrids at Different Environments, M. Sc., thesis (1991), Faculty of Agriculture, Khartoum University, Sudan.

[19] A.O.A.C., Official methods for analysis. $13^{\text {th }}$ Ed. Association of Official Analytical Chemist (1980) Washington.

[20] W.G. Cochran, G.M. Cox, Experimental designs, $2^{\text {nd }}$ edn. John Wiley and Sons, Inc. New York. (1957) 293-316. 
[21] Genstat, Ninth edition. Version - 9.1.0.174.Lawes Agricultural Trust (Rothamsted Experimental Station) VSN International, Hertfordshire (2011).

[22] Feedipedia, Maize green forage, Animal feed resources information system - INRA CIRAD AFZ and FAO Available at : http://www.feedipedia.org/node/358. (2016).

[23] D.R. Mertens. Predicting intake and digestibility using mathematical models of ruminal function, J. Anim. Sci. 64 (1987) 1548-1558.

[24] R. Montgomery, Influence of corn hybrids and water stress on yield and nutritive value. Texas Tech University Libraries, Electronic Theses and Dissertations. DSpace software, Available: http://hdl.handle.net/2346/18065. (2009).

[25] C.H. Robert, K.T. Edward, Effects of drought stress on corn production, ExEx 8033. Available: http://agbiopubs.sdstate.edu/articles/ExEx8033.pdf. (2002).

[26] T.Z. Zsuzsanna et al., Yield and chemical composition of plant parts of silage maize (Zea mays L) hybrids and their interest for biogas production, Agricultural Institute, Centre for Agricultural Research, Hungarian Academy of Sciences, H-2462 Martonvásár, Hungary. (2013).

[27] J. Silva, Factors affecting production of forage maize, Retrospective theses and dissertations, Paper 6853. (1981).

[28] J.L. Moyer, J.O. Fritz, J.J. Higgins, Relationship among forage yield and quality factors of haytype sorghums, Crop management. (2003). doi: 10.1094/CM-2003-1209-01-RS.

[29] M.I. Mohammed, Z.A. Zakaria, Quality attributes in Sudanese sorghum improved for forage yield, Americ. J. of Expt. Agric. 4 (2014)171-182.

[30] A.K. Reddy, V. Chaitanya, N. Vivekanandan, Drought induced respond of photosynthesis and antioxidant in higher plant, Journal of Plant physiology. 161 (2004) 1189-1202.

[31] J.O. Payero et al., Effect of timing of a deficit-irrigation allocation on corn evapotranspiration, yield, water use efficiency and dry mass, Agricultural Water Management. 96 (2009) 13871397.

[32] A. Wahid, et al., Heat tolerance in plants: An overview, Environ. Exp. Bot. 61 (2007) 199-223. 